\title{
Sexual Dimorphism of Anthropometric Measurements of Periorbital Soft Tissues in a Sample of Egyptian Adults
}

\author{
${ }^{1}$ Rania Hamed Abdel-Rahman, ${ }^{2}$ Sherif Gamal AbdAllah Amr, ${ }^{3}$ Ahmed Abdel-Galil Khalil
}

\begin{tabular}{|c|c|}
\hline & ABSTRACT \\
\hline $\begin{array}{l}\text { KEYWORDS } \\
\text { Periorbital, } \\
\text { Forensic, } \\
\text { identification, } \\
\text { Sexual dimorphism, } \\
\text { Egyptians. }\end{array}$ & $\begin{array}{l}\text { The periorbital soft-tissue characteristics provide an immense number of } \\
\text { anatomical landmarks which could help in various forensic investigations. This work } \\
\text { aimed to assess the forensic value of anthropometric measurements of periorbital } \\
\text { soft tissue landmarks in sex discrimination. Two hundred Egyptian healthy young } \\
\text { individuals of both sexes were included in the study. Their ages ranged from 18-40 } \\
\text { years. The following anthropometric measures were estimated for all participants: } \\
\text { inter-inner canthal width (IICD), inter-outer canthal width (IOCD), horizontal } \\
\text { palpebral width (HPD), orbital height, upper and lower eyelids heights in addition to } \\
\text { some computed orbital indices. A significant difference was found between males and } \\
\text { females regarding the IICD, IOCD, HPD, palpebral fissure index and left orbital } \\
\text { index. The current observations provide a database for adult periorbital } \\
\text { anthropometry in Egyptians. Also, they could aid in personal identification and sex } \\
\text { differentiation especially when combined with other facial characteristics. Further } \\
\text { anthropometric studies on periorbital soft tissue landmarks are warranted using } \\
\text { other modern techniques such as digital photography and software image analysis } \\
\text { for documentation of antemortem data which could aid the process of forensic } \\
\text { identification in civil and criminal medicolegal investigations. }\end{array}$ \\
\hline
\end{tabular}

\section{Introduction}

Personal identification greatly depends on facial characteristic information. Documentation of different ethnic normative database in various populations may help in the identification process (Shi et al., 2006; Roelofse et al., 2008). Moreover, facial reconstructions in forensic investigations require data collection from living persons to supply information that may be helpful in simulating the modifications of facial features. This could aid the forensic examiner to solve

\footnotetext{
${ }^{(1)}$ Forensic Medicine and Clinical Toxicology Department, Faculty of Medicine, Mansoura University, Egypt.

(2) Plastic Surgery, Mansoura New General Hospital.

(3) Plastic, Reconstructive and Burn Surgery Department, Mansoura Faculty of Medicine, Egypt
}

the criminal cases of impersonation and to recognize the craniofacial complex (Stephan, 2002; Fraser et al., 2003). Presence of antemortem standardized personal images will also help in comparison of the different facial features in criminal cases and in postmortem identification (Sforza and Ferrario, 2006; Agrawal et al., 2013).

Interestingly, one of the most commonly used features for personal recognition is the soft-tissue facial characteristics. An enormous set of dimensions that are claimed to remain stable over time or have reduced age-related differences could be obtained from periorbital soft tissues. These dimensions could play a predominant role with other anthropometric landmarks in the evaluation and recognition of the craniofacial complex. They may help in personal 
identification even years after the actual crime (Sforza et al., 2009 and 2013).

Accordingly, reference anthropometric data of the orbital region are necessary for multiple forensic, medical diagnostic as well as surgical aesthetic procedures. For instance, antemortem and postmortem comparison of personal database, facial reconstruction, diagnosis of fetal alcohol syndrome, evaluation of traumas, gene alterations and teratogenicinduced conditions with periocular dysmorphology (Sforza et al., 2009; Vasanthakumar et al., 2013; Ozdemir et al., 2017).

Forensic investigations (aging and sexing of living and dead individuals, personal identification, facial reconstruction etc.) are increasingly needed much more than before, thus reference data on various ethnic groups is mandatory. Studies concerning periorbital and canthal measurements in Egyptian population are still scanty. Hence, the aim of the current work was to perform an anthropometric analysis of periorbital soft tissue landmarks to assess their forensic value regarding sex discrimination.

\section{Subjects and Methods}

\section{Subjects:}

The present study was conducted during the period between July 2016 and February 2018 at the Departments of Forensic Medicine and Clinical Toxicology; Plastic, Reconstructive and Burn Surgery, Faculty of Medicine, Mansoura University as well as Mansoura New General Hospital.
Participants were adult Egyptian healthy volunteers of both sexes aged from 18 to 40 years with normal location of the ear. Uncooperative individuals or those with previous exposure to facial trauma or surgery especially upper and midface and those having congenital facial anomaly or orbital diseases e.g. strabismus and ptosis were excluded from the study.

\section{Methods}

\section{Ethical consideration:}

The present study was approved by the Institutional Review Board, Faculty of Medicine, Mansoura University. Participants gave their informed consent about the procedure which was not invasive. The used instruments did not provoke pain, were not harmful, and were not potentially dangerous to the health of the subjects included in the study.

\section{Measurement of anthropometric periorbital soft tissues landmarks:}

The subject sat relaxed with his/her face properly illuminated and the head held straight to face the examiner. The following measurements were estimated for all individuals by one expert examiner using soft measuring tape and sliding caliper with measurement accuracy of $0.1 \mathrm{~mm}$. Table (a) and figures (1\&2) demonstrate the measured horizontal and vertical anthropometric landmarks and their description according to Evereklioglu et al. (2002) and Jajá et al. (2011). Then, canthal and orbital indices and ratios were computed as shown in table (b) as described by Jayaratne et al. (2013) and Mostafa et al. (2014). 
Table (a): Anthropometric horizontal and vertical periorbital soft tissue measurements and their description.

\begin{tabular}{|c|c|}
\hline $\begin{array}{c}\text { Periorbital horizontal } \\
\text { measurements }\end{array}$ & Description \\
\hline $\begin{array}{l}\text { Inter-innercanthal width } \\
\text { (IICD) }\end{array}$ & Distance between the inner canthi (endocanthions "en-en") of both eyes. \\
\hline $\begin{array}{l}\text { Inter-outercanthal width } \\
\text { (IOCD) }\end{array}$ & $\begin{array}{l}\text { Distance between the outer canthi (exocanhions "ex-ex") of both eyes } \\
\text { (Biocular width). }\end{array}$ \\
\hline $\begin{array}{l}\text { Horizontal palpebral } \\
\text { width (en-ex) (HPD) }\end{array}$ & $\begin{array}{l}\text { Distance between endocanthion \& exocanthion of each eye (Eye fissure } \\
\text { width). }\end{array}$ \\
\hline $\begin{array}{l}\text { Periorbital vertical } \\
\text { measurements }\end{array}$ & Description \\
\hline Orbital height (or-os) & $\begin{array}{l}\text { Distance between the lowest point of inferior orbital rim "orbitale" (or) and } \\
\text { the highest point on lower border of the eyebrow (orbital superius "os"). }\end{array}$ \\
\hline $\begin{array}{l}\text { Upper eyelid height } \\
\text { (eyebrow height) (os-ps) }\end{array}$ & $\begin{array}{l}\text { Distance between the highest point on lower border of eyebrow (os) and the } \\
\text { palpebrale superius (ps) which is the highest point on the free margin of the } \\
\text { upper eyelid (midportion) when the eye is opened. }\end{array}$ \\
\hline $\begin{array}{l}\text { Lower eyelid height (or- } \\
\text { pi) }\end{array}$ & $\begin{array}{l}\text { Distance between the palpebrale inferius (pi) which is the lowest point on the } \\
\text { free margin of the lower eyelid and the lowest point of inferior orbital rim } \\
\text { when the eye is opened. }\end{array}$ \\
\hline
\end{tabular}

Table (b): Anthropometric periorbital indices and their description.

\begin{tabular}{|l|l|}
\hline \multicolumn{1}{|c|}{ Periorbital indices } & \multicolumn{1}{c|}{ Description } \\
\hline Canthal index & $($ Intercanthal width/Biocular width $\times 100)$ \\
\hline Palpebral fissure index & $($ OCD-ICD $) / 2$ \\
\hline $\begin{array}{l}\text { Height of the orbit to the length of eye } \\
\text { fissure ratio (Right and left) }\end{array}$ & $($ os-or/en-ex $) / 100$ \\
\hline Eye fissure index (Right and left) & $($ ps-pi/ex-en $) \times 100$ \\
\hline $\begin{array}{l}\text { Right and left orbital index (Eye fissure } \\
\text { length to orbital height Index) }\end{array}$ & $\begin{array}{l}\text { En-ex }(\text { horizontal palpebral distance }) / \text { orbital height } \\
(\text { or-os }) \times 100\end{array}$ \\
\hline $\begin{array}{l}\text { Eye fissure length to intercanthal width } \\
\text { index (Right and left) }\end{array}$ & En-ex/en-en $\times 100$ \\
\hline $\begin{array}{l}\text { Eye fissure length-intercanthal width to } \\
\text { biocular width index }\end{array}$ & En-ex+en-en/ex-ex $\times 100$ \\
\hline
\end{tabular}



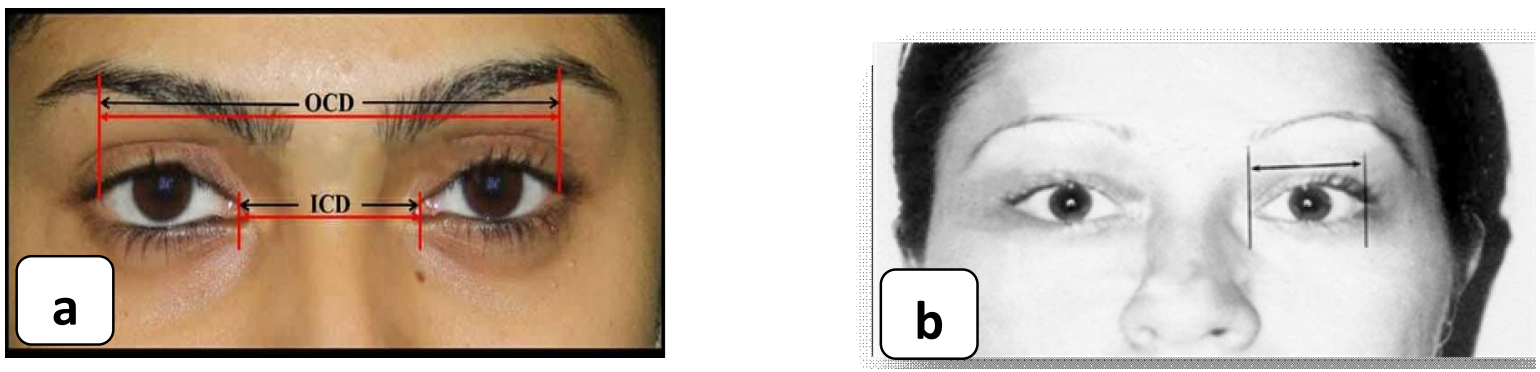

Fig. (1): (a) Inter-inner canthal distance (ICD), inter-outer canthal distance (OCD), (b) Horizontal palpebral distance.
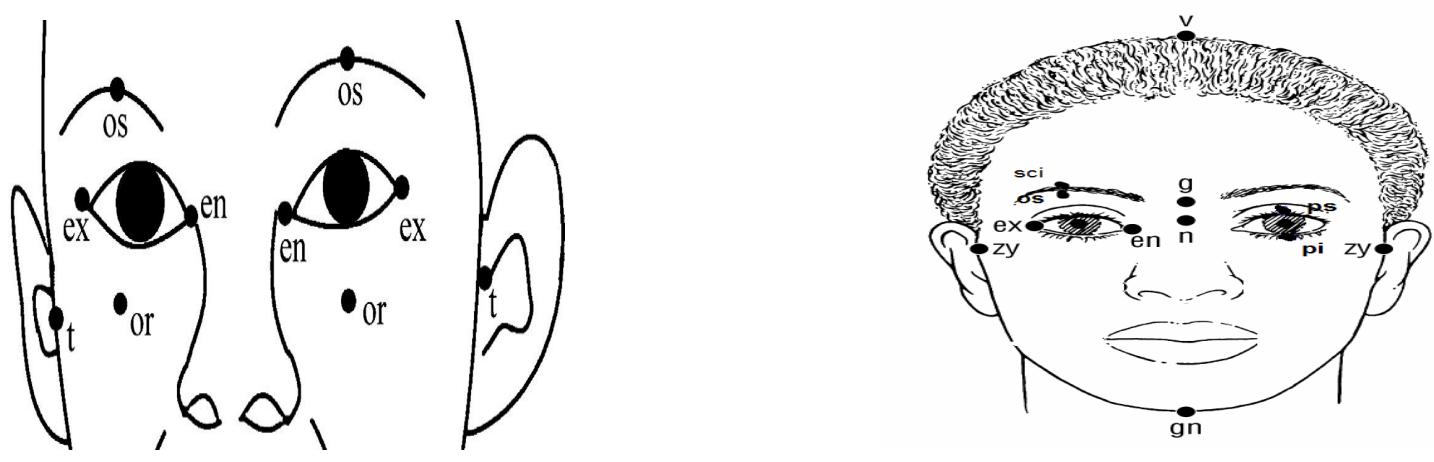

Fig. (2): Anterior views of anthropometric points of periorbital soft tissue endocanthion (en), exocanthion (ex), inferior orbital rim "orbitale" (or), the highest point on lower border of the eyebrow (orbital superius) "os", palpebrale superius (ps) which is the highest point on the free margin of the upper eyelid, palpebrale inferius (pi) which is the lowest point on the free margin of the lower eyelid, glabella "g", nasion " $n$ " which is the most prominent midline point between the eyebrows and is identical to the bony glabella on the frontal bone, gonion "go" which is the most lateral point on the angle of mandible close to the bony gonion; Tragion $(\mathrm{t})$ : it is the notch on the upper margin of the tragus Superciliare (sci) "the highest point on the upper border of each eyebrow in the mid-portion"

\section{Statistical Analysis}

Descriptive statistics (mean and standard deviation) for each measurement were computed within sex group. Data were analyzed with SPSS version 21 . The normality of data was first tested with one-sample Kolmogorov-Smirnov test. Continuous variables were presented as mean \pm SD (standard deviation). The two groups were compared with Student $t$ test while paired groups were compared with paired t-test. For all the above mentioned statistical tests, the threshold of significance is fixed at 5\% level (p-value). The results were considered significant when the probability of error $\leq 0.05$.

\section{Results}

The current study included one hundred males and one hundred females aged 18-40 years (Mean \pm SD: $24.5 \pm 5.6$ years). Table (1) illustrates the statistical analysis of anthropometric measurements of the periorbital soft tissue landmarks in male and female young adults. A highly significant difference was found between males and females regarding the horizontal measurements (Inter-innercanthal width, inter-outer canthal distance and horizontal palpebral distance). None of the vertical measurements showed a significant difference neither in males nor in females. 
Table (1): Descriptive statistics of anthropometric periorbital soft tissue measurements in the studied Egyptian sample $(\mathrm{n}=200)$.

\begin{tabular}{|c|c|c|c|c|c|}
\hline \multirow{2}{*}{$\begin{array}{l}\text { Measurements } \\
\text { (in millimeter) }\end{array}$} & \multirow[t]{2}{*}{ Side } & $\begin{array}{c}\text { Males } \\
(\mathrm{n}=100)\end{array}$ & $\begin{array}{c}\text { Females } \\
(n=100)\end{array}$ & \multirow[t]{2}{*}{ t-test } & \multirow[t]{2}{*}{ p-value } \\
\hline & & Mean \pm SD & Mean \pm SD & & \\
\hline \multicolumn{6}{|l|}{ 1) Horizontal parameters } \\
\hline IICD (en-en) & - & $33.8 \pm 2.2$ & $32.8 \pm 2$ & 3.209 & $0.002 * *$ \\
\hline IOCD (ex-ex) & - & $98.6 \pm 5.1$ & $95.8 \pm 2.8$ & 4.690 & $0.001 * *$ \\
\hline \multirow{2}{*}{ HPD (en-ex) } & LT & $32.4 \pm 1.7$ & $31.4 \pm 1.1$ & 4.97 & $0.001^{* *}$ \\
\hline & RT & $32.5 \pm 1.9$ & $31.4 \pm 1$ & 5.21 & $0.001 * *$ \\
\hline \multicolumn{6}{|l|}{ 2) Vertical parameters } \\
\hline \multirow{2}{*}{ Orbital height (or_os) } & LT & $32.4 \pm 3.1$ & $32.3 \pm 3.1$ & 0.31 & 0.75 \\
\hline & RT & $32.5 \pm 3$ & $32.1 \pm 3$ & 0.90 & 0.36 \\
\hline \multirow{2}{*}{$\begin{array}{l}\text { Upper eyelid height } \\
\text { (eyebrow height)(os_ps) }\end{array}$} & $\overline{\mathrm{LT}}$ & $9.5 \pm 1.8$ & $9.4 \pm 1.6$ & 0.40 & 0.68 \\
\hline & RT & $9.6 \pm 2.1$ & $9.3 \pm 1.6$ & 1.29 & 0.19 \\
\hline \multirow{2}{*}{ Lower eyelid height (or_pi) } & LT & $10.9 \pm 2.1$ & $10.5 \pm 2.0$ & 1.35 & 0.17 \\
\hline & RT & $10.9 \pm 2.3$ & $10.5 \pm 2.3$ & 1.47 & 0.14 \\
\hline
\end{tabular}

n: number, SD: standard deviation, IICD: inter-inner canthal distance, IOCD: inter-outer canthal distance, HPD: horizontal palpebral distance. LT: left, RT: right, ** highly significant.

The statistical analysis of the computed periorbital indices in the studied Egyptian sample is shown in table (2). A highly significant difference was found between both sexes regarding palpebral fissure index. Also, the left orbital index was significantly different when comparing males and females.

Table (2): Statistical analysis of periorbital indices in the studied Egyptian sample ( $\mathrm{n}=200)$.

\begin{tabular}{|c|c|c|c|c|c|}
\hline \multicolumn{2}{|l|}{ Indices } & \multirow{2}{*}{$\begin{array}{c}\begin{array}{c}\text { Males } \\
(n=100)\end{array} \\
\text { Mean } \pm \text { SD }\end{array}$} & \multirow{2}{*}{$\begin{array}{c}\begin{array}{c}\text { Females } \\
(n=100)\end{array} \\
\text { Mean } \pm \text { SD } \\
\end{array}$} & \multirow[t]{2}{*}{ t-test } & \multirow[t]{2}{*}{ p-value } \\
\hline & & & & & \\
\hline Canthal index & - & $34.30 \pm 1.37$ & $34.28 \pm 1.63$ & 0.103 & 0.92 \\
\hline Palpebral fissure index & - & $3.24 \pm 0.18$ & $3.15 \pm 0.10$ & 4.229 & $<0.001^{* *}$ \\
\hline \multirow{2}{*}{$\begin{array}{l}\text { Height of the orbit to length of eye fissure } \\
\text { ratio }\end{array}$} & LT & $100.23 \pm 10.32$ & $103.07 \pm 11.46$ & 1.841 & 0.07 \\
\hline & RT & $100.12 \pm 10.17$ & $102.52 \pm 11.31$ & 1.580 & 0.12 \\
\hline \multirow{2}{*}{ Eye fissure index } & LT & $29.43 \pm 5.79$ & $30.07 \pm 5.31$ & 0.816 & 0.42 \\
\hline & RT & $29.71 \pm 6.47$ & $29.67 \pm 5.39$ & 0.043 & 0.97 \\
\hline \multirow{2}{*}{ Orbital index } & LT & $100.75 \pm 9.73$ & $98.09 \pm 9.88$ & 1.951 & $0.05 *$ \\
\hline & RT & $100.84 \pm 9.66$ & $98.59 \pm 9.80$ & 1.631 & 0.11 \\
\hline \multirow{2}{*}{$\begin{array}{l}\text { Eye fissure length to intercanthal width } \\
\text { index (right and left) }\end{array}$} & LT & $96.02 \pm 4.96$ & $95.86 \pm 6.81$ & 0.198 & 0.84 \\
\hline & RT & $96.47 \pm 5.08$ & $95.94 \pm 6.71$ & 0.626 & 0.53 \\
\hline \multirow{2}{*}{$\begin{array}{l}\text { Eye fissure length-intercanthal width to } \\
\text { biocular width index }\end{array}$} & LT & $67.18 \pm 1.46$ & $67.03 \pm 1.12$ & 0.806 & 0.42 \\
\hline & RT & $67.33 \pm 1.43$ & $67.07 \pm 1.16$ & 1.455 & 0.15 \\
\hline
\end{tabular}

n: number, SD: standard deviation, LT: left, RT: right, ** highly significant 
Comparison between the measured left and right periorbital indices is shown in table (3). Both eye fissures length to intercanthal width index and eye fissure length-intercanthal width to biocular width index show a highly significant difference between the left and right sides in males. Whereas in females, both height of the orbit to the length of eye fissure ratio and eye fissure height-length ratio revealed a significant difference between the left and right sides.

Table (3): Statistical comparison of the studied anthropometric measurements between the left and the right sides in the studied Egyptian sample of both sexes $(n=200)$.

\begin{tabular}{|c|c|c|c|c|}
\hline \multirow{3}{*}{ Parameter } & \multicolumn{2}{|c|}{ Males $(n=100)$} & \multirow{3}{*}{$\begin{array}{l}\text { Paired t- } \\
\text { test }\end{array}$} & \multirow{3}{*}{ p-value } \\
\hline & Right & Left & & \\
\hline & Mean \pm SD & Mean \pm SD & & \\
\hline $\begin{array}{l}\text { Height of the orbit to length } \\
\text { of eye fissure ratio }\end{array}$ & $1.00 \pm 10.17$ & $1.00 \pm 10.32$ & 0.407 & 0.69 \\
\hline Eye fissure height-length ratio & $29.71 \pm 6.47$ & $29.43 \pm 5.79$ & 1.389 & 0.17 \\
\hline Orbital index & $1.00 \pm 9.66$ & $1.00 \pm 9.73$ & 0.293 & 0.77 \\
\hline $\begin{array}{l}\text { Eye fissure length to } \\
\text { intercanthal width index }\end{array}$ & $96.47 \pm 5.08$ & $96.02 \pm 4.96$ & 3.144 & $0.002 * *$ \\
\hline $\begin{array}{l}\text { Eye fissure length- } \\
\text { intercanthal width to biocular } \\
\text { width index }\end{array}$ & $67.33 \pm 1.43$ & $67.18 \pm 1.46$ & 3.130 & $0.002 * *$ \\
\hline \multirow[b]{2}{*}{ Parameter } & \multicolumn{2}{|c|}{ Females $(n=100)$} & \multirow{2}{*}{$\begin{array}{c}\text { Paired t- } \\
\text { test }\end{array}$} & \multirow[b]{2}{*}{ p-value } \\
\hline & $\begin{array}{c}\text { Right } \\
\text { Mean } \pm \text { SD }\end{array}$ & $\begin{array}{c}\text { Left } \\
\text { Mean } \pm \text { SD }\end{array}$ & & \\
\hline $\begin{array}{l}\text { Height of the orbit to length } \\
\text { of eye fissure ratio }\end{array}$ & $1.02 \pm 11.31$ & $1.03 \pm 11.46$ & 1.984 & $0.05 *$ \\
\hline Eye fissure height-length ratio & $29.67 \pm 5.39$ & $30.07 \pm 5.31$ & 2.095 & $0.04 *$ \\
\hline Orbital index & $98.59 \pm 9.80$ & $98.09 \pm 9.88$ & 1.823 & 0.07 \\
\hline $\begin{array}{l}\text { Eye fissure length to } \\
\text { intercanthal width index }\end{array}$ & $95.94 \pm 6.71$ & $95.86 \pm 6.81$ & 1.319 & 0.19 \\
\hline $\begin{array}{l}\text { Eye fissure length- } \\
\text { intercanthal width to biocular } \\
\text { width index }\end{array}$ & $67.07 \pm 1.16$ & $67.03 \pm 1.12$ & 1.366 & 0.17 \\
\hline
\end{tabular}

n: number, SD: standard deviation. *significant, ** highly significant 
Data of logistic regression analysis is demonstrated in table (4). The interinnercanthal distance, inter-outercanthal distance, the right and left eye fissures and palpebral fissure indices are highly significant predictors for male sex. Data of Roc curve analysis is shown in table (5). It reveals that the accuracy of prediction of male sex using the palpebral fissure index and the eye fissure index equals $65.5 \%$ and $65 \%$ respectively.

Table (4): Logistic regression analysis of independent predictors for male sex.

\begin{tabular}{|l|c|c|c|c|}
\hline \multicolumn{1}{|c|}{ Independent predictors } & $\boldsymbol{\beta}$ & $\mathbf{p}$-value & OR & 95\% CI (OR) \\
\hline Inter-innercanthal width (IICD) & 2.19 & $0.002^{* *}$ & 8.96 & $2.19-36.62$ \\
\hline Inter-outercanthal width (IOCD) & 1.81 & $0.001^{* *}$ & 6.11 & $2.59-14.38$ \\
\hline Palpebral fissure index & 4.339 & $0.001^{* *}$ & 65.12 & $6.261-177.3$ \\
\hline Right eye fissure index & 5.41 & $0.001^{* *}$ & 23.35 & $11.23-34.9$ \\
\hline Left eye fissure index & 5.12 & $0.001^{* *}$ & 67.84 & $17.21-163.7$ \\
\hline Left orbital index & 0.028 & 0.06 & 1.03 & $0.99-1.06$ \\
\hline
\end{tabular}

Constant $=-13.99$, OR: odds ratio, CI: confidence interval, $* *$ highly significant

Table (5): Data of ROC curve analysis for prediction of male sex by the estimated anthropometric periorbital soft tissues measurements

\begin{tabular}{|l|c|c|c|c|c|c|c|c|}
\hline \multicolumn{1}{|c|}{ Parameter } & AUC & $\mathbf{9 5 \%}$ CI & Cutoff & Sensitivity & Specificity & PPV & NPV & Accuracy \\
\hline IICD & 0.603 & $0.52-0.68$ & $>3.35$ & $59 \%$ & $60 \%$ & $58 \%$ & $60 \%$ & $59 \%$ \\
\hline IOCD & 0.662 & $0.59-0.74$ & $>9.55$ & $67 \%$ & $56 \%$ & $60.4 \%$ & $62.9 \%$ & $61.5 \%$ \\
\hline PFI & 0.651 & $0.57-0.73$ & $>3.15$ & $75 \%$ & $57 \%$ & $57.2 \%$ & $63.7 \%$ & $65.5 \%$ \\
\hline $\begin{array}{l}\text { Right eye fissure } \\
\text { index }\end{array}$ & 0.692 & $0.62-0.77$ & $>3.15$ & $68 \%$ & $62 \%$ & $64.1 \%$ & $65.9 \%$ & $65 \%$ \\
\hline $\begin{array}{l}\text { Left eye fissure } \\
\text { index }\end{array}$ & 0.683 & $0.61-0.76$ & $>3.15$ & $68 \%$ & $62 \%$ & $64.1 \%$ & $65.9 \%$ & $65 \%$ \\
\hline
\end{tabular}

PFI: Palpebral fissure index, IICD: Inter-innercanthal width, IOCD: Inter-outercanthal width, AUC: area under the curve, CI: confidence interval, PPV: positive predictive value, NPV: negative predictive value 


\section{Discussion}

The determination of normal values for the periorbital region by making anthropometric studies in the living individuals is important in terms of forensic investigations for personal identification and comparison of antemortem and postmortem records (Sforza et al., 2013).

As far as we are aware, this is the first study in Egypt that aims to analyze the forensic role of periorbital and canthal measurements concerning sex discrimination. In the present work, males have statistically significant greater measurements than females as regard the inter-inner canthal distance (IICD) $\quad(33.8 \pm 2.2$ and $32.8 \pm 2 \quad \mathrm{~mm}$ respectively) as well as inter-outer canthal distance (IOCD) $(98.6 \pm 5.1 \mathrm{~mm}$ in males and $95.8 \pm 2.8 \mathrm{~mm}$ in females) and the horizontal palpebral distance (HPD) "32.5 $\pm 1.9 \mathrm{~mm}$ compared to $31.4 \pm 1 \mathrm{~mm}$ in females".

The present findings are nearly similar to Malays where the IICD was $33.9 \pm 1.9 \mathrm{~mm}$ in males and $32.5 \pm 1.7 \mathrm{~mm}$ in females. Moreover, the IOCD values were $(92.3 \pm 4.1 \mathrm{~mm}$ for males and $89.6 \pm 3.2 \mathrm{~mm}$ for females (Ngeow \& Aljunid, 2009) which were shorter than those found in the current work.

Also, shorter ICD measurements were reported in Saudi-Arabian males and females "32.7 $\pm 2.8 \mathrm{~mm}$ and $31.3 \pm 3.5 \mathrm{~mm}$ respectively" (Bukhari, 2011) and in Indians " $32.8 \pm 1.7 \mathrm{~mm}$ and $32.7 \pm 1.5 \mathrm{~mm} "$ (Packiriswamy et al., 2013).

Higher estimated canthal measurements were reported by other researchers. For instance, Egwu et al. (2008) found that Nigerian males and females had much longer IOCD values $\quad(118.34 \pm 0.66 \mathrm{~mm}$, $114.76 \pm 0.34 \mathrm{~mm}$ respectively). Onakpoya et al. (2012) reported much longer mean values for ICD in Negro Nigerian population: $37.1 \mathrm{~mm}$ in males and $35.2 \mathrm{~mm}$ in females, as well as OCD measurements: $101 \mathrm{~mm}$ in males compared to $96.9 \mathrm{~mm}$ in females).

Also, much smaller IICD measurements were estimated in North-Sudanese males $(29.1 \pm 2.5 \mathrm{~mm})$ and females $(28.8 \pm 3.5 \mathrm{~mm})$ while the IOCD showed higher mean values $(111.5 \pm 8.3 \mathrm{~mm}$ for males $101.1 \pm 8.1 \mathrm{~mm}$ for females) as stated by Sforza et al. (2013) which exceed the values measured in the Egyptians studied in the present work.

In the same context, Ozdemir et al. (2017) investigated the anthropometric measurements in a Turkish population and found shorter IICD measurements $(30.7 \pm 2.6$ in males and $30.1 \pm 2.6$ in females) and much lesser IOCD and HPD values than those reported in the present Egyptian population (IOCD: $83.4 \pm 4.8$ and $81.9 \pm 4.6$, HPD: $27 \pm 1.8$ and $26.7 \pm 1.8$ in males and females respectively). The authors also stated that measurements of right and left vertical palpebral apertures as well as left and right eyebrow heights were predominantly different in both sexes.

The present HPD results in males are nearly similar to that of Indians $(32.3 \pm 2.2 \mathrm{~mm})$ with a little difference for HPD in females $(33.7 \pm 1.8 \mathrm{~mm})$. (Patil et al., 2011) and from that of Saudi-Arabians $(30.8 \pm 2.9 \mathrm{~mm}$ for males and $29.5 \pm 2.8 \mathrm{~mm}$ for females (Bukhari, 2011). Contradictory to the present finding, Sforza et al. (2013) found that the HPD is much longer in north-Sudanese males " $48 \pm 4.3 \mathrm{~mm}$ " as well as in females " $41.4 \pm 5.7 \mathrm{~mm} "$.

The discrepancy between the present findings and other studies are due to many factors including age, race, ethnic group and sample size of the studied population as well as the applied method and tools used for taking the measurements. Differences highlight the importance of data collection in every ethnic group and different populations in different ages. 
Sexual dimorphism of the previously mentioned anthropometric parameters has been reported in various studies (Onakpoya et al., 2012; Acar et al., 2017; Ozdemir et al., 2017). In general, sex differences in canthal measurements could be attributed to environmental and genetic factors (Oyinbo et al., 2008).

As regard the computed indices analyzed in the present work, it is found that both palpebral fissure index and the left orbital index are greater in males $(3.24 \pm 0.18$ and $100.75 \pm 9.73$ ) and revealed a significant difference compared to females $(3.15 \pm 0.10$ and 98.09 \pm 9.88 ). Additionally, no significant difference is noticed between both sexes concerning the canthal index $(34.30 \pm 1.37$ for males and $34.28 \pm 1.63$ for females).

In addition, comparing the right and left eye fissures length to intercanthal width index in males $(96.47 \pm 5.08$ and $96.02 \pm 4.96$ respectively) as well as the right and left eye fissures length-intercanthal width to biocular width index $(67.33 \pm 1.43$ and $67.18 \pm 1.46$ respectively) reveal a highly significant difference between both sides. Interestingly, studying these indices in females is nonsignificant. However, a statistical significant difference is noticed in females when comparing the values of the right and left height of the orbit to length of eye fissure ratio $(1.02 \pm 11.31$ and $1.03 \pm 11.46)$ as well as eye fissure height-length ratio on right and left sides $(29.67 \pm 5.39$ and $30.07 \pm 5.31$ respectively).

Similarly, Jayaratne et al. (2013) found no sex difference regarding the canthal index $(43.95 \pm 8.23$ in males and $43.29 \pm 2.35$ in females) while both left and right eye fissure height-length ratios were significantly larger in females. In addition, Vasanthakumar et al. (2013) studied some anthropometric parameters in South Indians and reported a significant sexual dimorphism as regard palpebral fissure width and outercanthal distance. While the intercanthal distance and palpebral fissure height revealed no significant sexual variation.

In contrast, $\mathrm{Wu}$ et al. (2010) found significant differences between males and females concerning right and left eye fissure height measurements. This could be explained by the imprecise description of palpebrale superius (ps) and palpebrale inferius (pi) and use of their designed definition instead of applying the standardized description in textbooks (Jayaratne et al., 2013).

Conversely, Mostafa et al. (2014) analyzed the same orbital indices in 100 Bangladeshi females. They found different values where the canthal index $(39.42 \pm 2.09)$, right eye fissure length to intercanthal width index (75.38 \pm 6.62), left eye fissure length to intercanthal width index $(77.78 \pm 7.25)$, right eye fissure length-intercanthal width to biocular width index (69.01 \pm 1.49$)$, left eye fissure lengthintercanthal width to biocular width index (69.94 \pm 1.11 ), right eye fissure length to orbital height index $(64.71 \pm 5.16)$ and left eye fissure length to orbital height index $(66.36 \pm 5.04)$. The discrepancy between various studies confirms that the periorbital measurements differ significantly among various populations of different races, sexes, ages and ethnicity.

Regarding sex discrimination through the estimated periorbital measurements in the current work, the most significant parameters that could be used in prediction of sex are the ICD, OCD, indices of the right and left eye fissures and palpebral fissure index. PFD is found to be the most sensitive (75\%) with moderate accuracy $(65.5 \%)$. This necessitates the addition of other facial anthropometric measurements to increase their predictability and accuracy of sex determination. Noteworthy, Vasanthakumar et al. (2013) reported a significant sexual dimorphism concerning two 
parameters (the palpebral fissure width and the outercanthal distance). While the palpebral fissure height and the intercanthal distance revealed no statistically significant differences between both sexes.

It is worth to mention that the previously published anthropometric studies investigated the orbital measurements in dry skulls. They declared sexual dimorphism in the examined crania regarding the measured orbital anthropometric parameters (Jain et al., 2015; Avelar et al., 2017). On the other hand, Ezeuko and Udemezue (2015) failed to determine sex through radiographic measurements of the orbital margin in Nigerian Adults.

\section{Conclusion}

Findings observed in the present research could serve as a database for the comparative quantitative analysis and description of adult periorbital anthropometry in Egyptians. Additionally, they could be added to other facial anthropometric features to help in determination of sex increasing the accuracy of personal identification. It is recommended to perform further orbital anthropometric Egyptian studies to assess their value in discrimination of sex in both living and dead individuals. Also, the use of modern technology for taking the measurements such as different non-invasive photographic and digital applications as well as software image analysis may help in forensic investigations in civil and criminal cases involving facial reconstruction which could facilitate the documentation of all facial characteristics of an individual aiding the process of identification.
References

Acar, M.; Alkan, S.B.; Ulusoy, M.; et al. (2017): "An assessment of the face on Turkish and African students". Biomedical Research, 28 (9): 4177-4180.

Agrawal, J.; Yogesh, A.S.; Shukla, C.K.; et al. (2013): "Orbitofacial anthropometric assessment of inter-canthal and outercanthal distance measurement in Chhattisgarh region". Biomedical Research, 24 (3): 365-369.

Avelar, L.E.T.; Cardoso, M.A.; Bordoni, L.S. et al. (2017): Aging and sexual differences of the human skull. Plast. Reconstr. Surg. Glob. Open, 5:e1297.

Bukhari, A.A. (2011): "The distinguishing anthropometric features of the Saudi Arabian eyes". Saudi J .Ophthal., 25:417.

Egwu, O.A.; Ewunonu, E.O.; Etuedo, A.N.; et al. (2008): "Normal values of inner and outer intercanthal distances in a student population in southeast Nigeria." Int. J. Biol. Chem. Sci., 2(3):355.

Evereklioglu, C.; Doganay, S.; Hamdi, Er.; et al. (2002): "Craniofacial anthropometry in a Turkish population". Cleft Palate Craniofac. J., 39:208-218.

Ezeuko, V.C. and Udemezue, O.O. (2015): Sex cannot be determined through orbital margin anthropometry: A radiographic study of the aditus orbitae of adult Igbos of Nigeria. Annals of bioanthropology, $3(2): 50-54$.

Fraser, N.L.; Yoshino, M.; Imaizumi, K.; et al. (2003): "A Japanese computerassisted facial identification system 
successfully identifies non-Japanese faces." Forensic Sci. Int., 135:122128.

Jain, D.; Jasuja, O.P. and Nath, S. (2015): "Determination of sex using orbital measurements". Int. J. Phys. Anthrop. \& Hum. Genet., 34 (1): 97-108.

Jajá; B. N.R.; Fawehinmi, H.B. and Jack, J.T. (2011): "Craniofacial anthropometry in a young Nigerian population: the canthal distances." Int. J. Morphol., 29(3):914-917.

Jayaratne, Y.S.N.; Deutsch, C.K. and Zwahlen, R. A. (2013): "Normative findings for periocular anthropometric measurements among Chinese young adults in Hong Kong." BioMed. Research International. Article ID 821428.http://dx.doi.org/10.1155/2013 1821428.

Mostafa, A.; Banu, L.A. and Sultana, A. (2014): "Periocular anthropometric study among adult Bangladeshi Buddhist Chakma females". J. Med. Allied Sci., 4 (1): 28-34.

Ngeow, W.C. and Aljunid, S.T. (2009): "Craniofacial anthropometric norms of Malays". Singapore Med. J., 50(5):525.

Onakpoya, O. H.; Esan, T.A. and Oziegbe, E. O. (2012): "Orbito-ocular soft tissue measurements in young adults - an indigenous Negro population study". Orbit, 31(4): 207210.

Oyinbo, C. A.; Fawehinmi, H. B.; Dare, N.W. and Berezi, M. A. (2008): "Normal inner and outer measurements of the Ijaws of
Southern Nigeria." Eur. J. ScL Res., 22(2): 163-167.

Ozdemir, T.; Can, F.E.; Isiklar, S.; et al. (2017): "Periorbital soft tissue anthropometric analysis of young adults." J. Craniofac. Surg., 28(4): e311.

Packiriswamy, V.; Kumar, P. and Bashour, M. (2013): "Photogrammetric analysis of eyebrow and upper eyelid dimensions in South Indians and Malaysian South Indians". Aesth. Surg. J., 33:975-982.

Patil, S.B.; Kale, S.M.; Math, M.; et al. (2011): "Anthropometry of the eyelid and palpebral fissure in an Indian population." Aesthet. Surg. J., 31:290294.

Roelofse, M.M.; Steun, M.P. and Becker, J. (2008): "Photo identification: facial metrical and morphological features in South African males." Forensic Sci. Int., 177: $168-175$.

Shi, J.; Samal, A. and Marx, D. (2006): "How effective are landmarks and their geometry for face recognition"? Comput. Vis. Image Understand., 102: 117-133.

Stephan, C.N. (2002): "Position of superciliare in relation to the lateral iris: testing a suggested facial approximation guideline." Forensic Sci. Int., 130:29-33.

Sforza, C.; Elamin, F.; Tommasi, D.G.; et al. (2013): "Morphometry of the soft tissues of the orbital region in Northern Sudanese persons." Forensic Sci. Int., $228 \mathrm{e} 1$.

Sforza, C. and Ferrario, V.F. (2006): "Softtissue facial anthropometry in three dimensions: from anatomical landmarks to digital morphology in research, clinics 
and forensic anthropology." J. Anthropol. Sci., 84: 97-124.

Sforza, C.; Grandi, G.; Catti, F.; et al. (2009): "Age- and sex-related changes in the soft tissues of the orbital region." Forensic Sci. Int., 185:115.e1-115.e8.

Vasanthakumar, P.; Kumar, P. and Rao, M. (2013): "Anthropometric analysis of palpebral fissure dimensions \& its position in South Indian ethnic adults." Oman Med. J., 28(1):26.

Wu, X.-S.; Jian, X.-C.; He, Z.-J.; et al. (2010): "Investigation of anthropometric measurements of anatomic structures of orbital soft tissue in 102 young Han Chinese adults." Ophthalmic Plastic and Reconstructive Surgery, 26(5): 339-343. 


\title{
تمييز الجنس من القياسات البشرية للأنسجة الرخوة المحيطة بحجاج العين فى عينة من الصريين البالغين
}

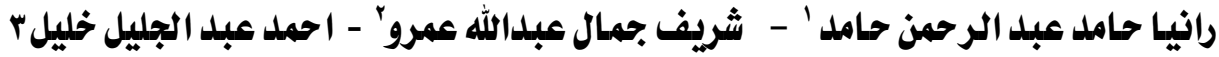

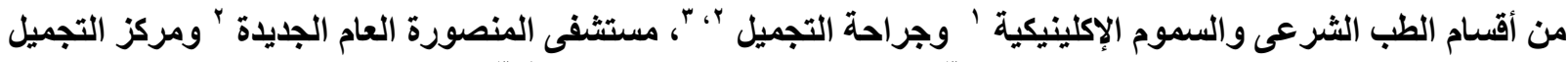

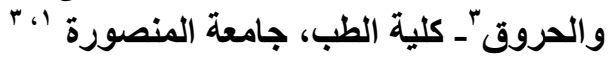

توفر خصائص الأنسجة الرخوة حول حجاج العين عددا هائلا من المعالم التشريحية التي يمكن أن تساعد في مختلف التحقيقات الطبيـة الشرعية. ويهدف هذا العمل إلى تقييم الأهميـة الطبيـة الثر عية للقياسـات البشرية

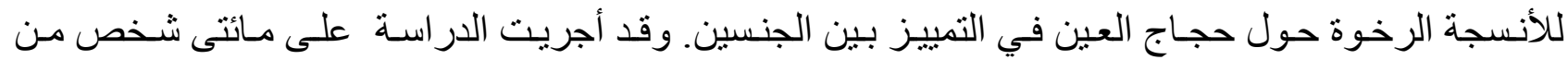

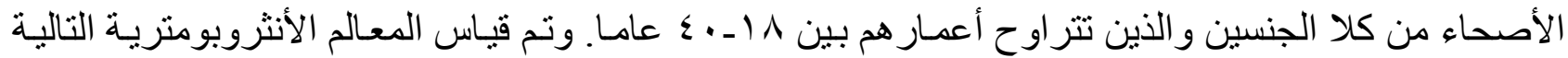

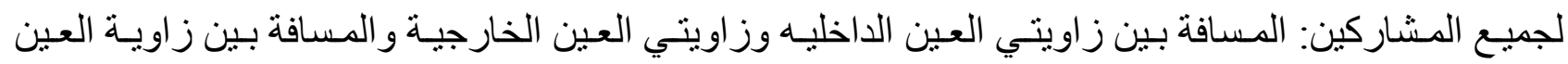
الداخليه و الخارجيه (العرض الأفقى للجفن) وارتفاع كلا من الجفن العلوي و الجفن السفلي كذلك المسافة بين أدنى نقطة في حافة حجـاج العين وأعلى نقطة على الحد السفلي من الحاجب وارتفاع الحاجب في الجانبين الأيمن و الأيسر كما تم حساب بعض المؤشرات القياسية الأنثروبومترية للمعالم السالف ذكر ها.

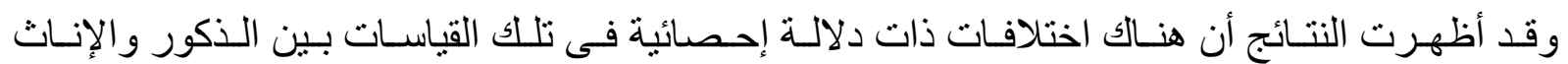
فيما يتعلق بالمسافة بين زاويتي العين الداخليه كذلك المسافة بين زاويتي العين الخارجية، و العرض الأفقى للجفن إحن وكذللك طول الشت الجفنى والمؤشر الإحصائى لحجـاج العين الأيسر ـ وبنـاءا على ماتقدم توفر النتائج الحاليـة

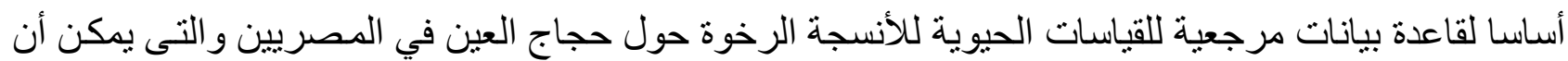

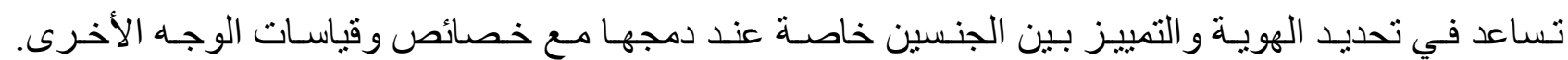
كما يمكن استخدامها في التحقيقات الطبية الثر عية في مختلف القضايا المدنية والجنائية التي تتعلق بالإستعر اف

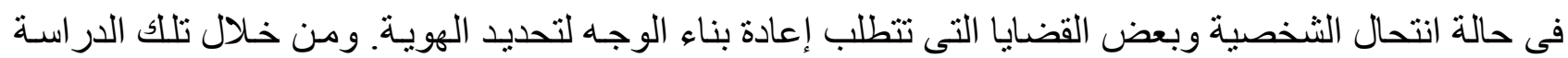

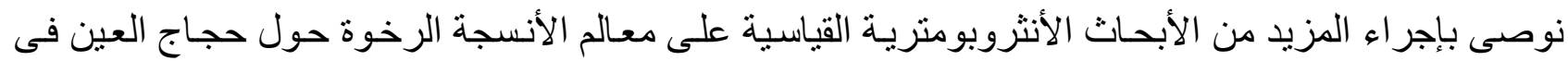

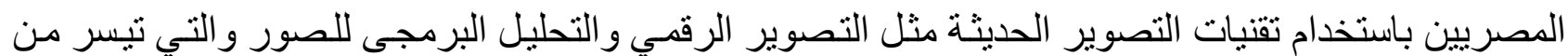

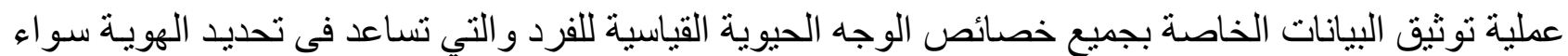
فى التحقيقات الطبية الثرعية المدنية أو الجنائية. 